\title{
The Effect of Implementation of Inquiry-based Learning with Socio- scientific Issues on Students' Higher-Order Thinking Skills
}

\author{
Sitti Nurul Qamariyah¹, Sri Rahayu1, Fauziatul Fajaroh¹, Naif Mastoor Alsulami² \\ ${ }^{1}$ Department of Chemistry Education, Faculty of Mathematics and Science, Universitas Negeri Malang, Indonesia \\ ${ }^{2}$ Graduate Studies, University of Jeddah, Jeddah, Saudi Arabia \\ *Corresponding Author sri.rahayu.fmipa@um.ac.id
}

\begin{abstract}
This study investigates the effect of inquiry-based learning with socio-scientific issues on students' higher-order thinking skills in the first year based on chemistry topics. This study used a quasi-experiment design as a method. A sample of 96 students in three classes was selected and was divided into two groups. An experimental group used two classes (68 students) that received the instruction by inquiry-based learning with socio-scientific issues, while the control group (28 students) received instruction using verification learning. The data were collected using pretest and post-test. The results were analyzed using SPSS 16.0 for windows software by employing ANOVA and effect size. This study showed that the experimental groups have a higher score in Higher Order Thinking Skills than the control group students, and there was a significant difference between the experimental groups and the control group with a large effect size. Thus, this study concluded that inquiry-based learning with socio-scientific issues helps conduct the classroom's learning strategies to improve students' higher-order thinking skills.
\end{abstract}

Keywords Inquiry, Socio-scientific issues, Higher order thinking skills

\section{INTRODUCTION}

The development of science and technology has both positive and negative impacts. The positive impact of this development is everything becomes fast and easy to improve life quality. Meanwhile, the negative impact is individuals' exposure to various problems related to ethics, morals, and global issues that can threaten human dignity and survival (Rahayu, 2016). It is necessary to build a society with scientific literacy abilities through the educational process. Scientific literacy skills are essential to be mastered by students because of their relation to concern for the surrounding environment and social issues. Scientific literacy skills will create a desire to solve problems or social issues around them (Graber, Neumann, Erdmann, \& Schlieker, 2006).

Solving problems related to the environment or social issues will expose a person to several different scientific, social, or moral viewpoints (Zeidler \& Nichols, 2009). Therefore, meaning-making needs to be done to connect what they learn with environmental problems around them (Sadler, 2009). The creation of meaning will occur when individuals can transfer what they know to other conditions. The transfer process is unlimited to remembering the knowledge that is owned. Still, it is also related to using knowledge or things that have been learned to other experiences or conditions (Brookhart, 2010). Thus, the learning process is not enough to transfer information to remember and store it in the brain, but it needs education that helps students have thinking skills (Rahayu, 2016; Subiantoro, 2017).

Thinking skills refer to mental activities that allow individuals to make meanings for various information obtained to form relevant knowledge to solve problems (Subiantoro, 2017). Thinking skills encourage individuals to think critically and creatively in decision-making and problem-solving. Such thinking skills well-known as higher-order thinking skills (HOTS). HOTS will cause individuals became an adapt to the development of science and technology. HOTS include critical, logical, reflective, metacognitive, and creative thinking skills (Nurohman, Wibowo, \& Widhi H, 2013; Shidiq, Masykuri, \& Susanti, 2015). HOTS based on Bloom's taxonomy includes analysis, evaluation, and synthesis skills. Higher-order thinking skills - analysis, evaluation, and synthesis or creation - are HOTS categories as transfer (Brookhart,

Received: 01 January 2021

Revised: 19 March 2021

Published: 01 July 2021 
2010). Not all individuals can spontaneously think at high levels, but they need encouragement, guidance, or habituation in these skills.

Chemistry is closely related to social science problems; for example, global warming and ecosystem damage can direct individuals to relate conceptual material to issues around them (Mahanani, Rahayu, \& Fajaroh, 2020). It makes Chemistry becomes a subject that can contribute to training student's HOTS. However, the presence of a lot of chemistry content can cause students unable to know how to form what relationships are obtained from the learning process with how to give meaning to what is learned (Tsaparlis, 2020). It also causes the assumption that chemistry is boring, difficult to understand, and irrelevant to everyday life (Cardellini, 2012), so students will only tend to memorize. Therefore, it is necessary to have learning chemistry, which allows students to experience learning by constructing meaning, which means students are actively involved in building concepts independently. One of the methods that accommodate is learning by inquiry.

The inquiry-based learning process allows students to find, decide, and use various sources of information and ideas, which are used to improve understanding of problems or phenomena (Kaltakci \& Oktay, 2011). Inquiry-based learning will ensure that students get the knowledge and become actively involved in the process (Malik, Ertikanto, \& Suyatna, 2015). Previous research has shown that inquiry-based learning can improve students' HOTS, including inquiry-based learning to enhance HOTS on reaction rate material (Hendryarto \& Amaria, 2013). Another research compares conventional learning and inquiry-based learning in improving HOTS (Madhuri, Kantamreddi, \& Goteti, 2012). Based on these results, it can be concluded that inquiry-based learning in other chemistry topics, one of which is acid-base, may improve HOTS. However, the research of Hendryarto \& Amaria (2013) and Madhuri, Kantamreddi, \& Goteti (2012) that has been carried out only focuses on the topics of learning. If students focus on the topics, it can cause students not to relate the temporal context to the events around them (Subiantoro, 2017; Sadler, 2009). There is a gap between abstract concepts and the reality of events around them (Mahanani, Rahayu, \& Fajaroh, 2020). Therefore, learning was needed to relate to everyday life, namely by providing relevant context. The teacher should shape the context to lead students to engage in the learning process to understand, reflect, and create meaningful knowledge (Sadler \& Zeidler, 2004; Subiantoro, 2017). One context that can be used is socio-scientific issues (SSI).

SSI are problems related to science and social content that are unstructured, have uncertain solutions, complex, and related to morals and ethics (Eastwood, et al., 2012; Sadler, 2004; Sadler \& Zeidler, 2004; Zeidler, Sadler, Applebaum, \& Callahan, 2009). SSI describes social dilemmas related to conceptual, procedural, or technological relationships in social science problems (Sadler \& Zeidler, 2004). SSI is controversial and requires a level of moral reasoning and associated evaluation/ethics in the decision-making process for solving problems (Zeidler \& Nichols, 2009). SSI will encourage individuals to reflect and relate relevantly between science and several scientific points of view, resulting in conflicts with held beliefs or others' beliefs (Zeidler, Sadler, Applebaum, \& Callahan, 2009). The resulting conflict will lead individuals to analyze, evaluate, and synthesize sources, knowledge, or evidence to produce justification (Kitchener \& King, 1981; Zeidler, Sadler, Applebaum, \& Callahan, 2009). SSI has a role in providing global issues and making individuals prepare themselves to deal with this (Sadler \& Murakami, 2014). The involvement of the SSI context will create learning where individuals face complex decision-making problems that are factually, conceptually, and ethically related to ethics and morals (Paraskeva-Hadjichambi, Hadjichambis, \& Korfiatis, 2015). It means that SSI learning will train students to analyze problems, evaluate the sources to be used, and create solutions. In learning by using SSI, there is an interaction between three components; educators (lecturers), students, and the context of the problems that must be solved (Imaduddin \& Khafidin, 2018; Kristiana, Afandi, \& Wahyuni, 2019). That description is proven by similar research but on different variables and topics: inquiry-based learning on the contextbased SSI can improve critical thinking skills (Mahanani, Rahayu, \& Fajaroh, 2020). Based on the research described, research studies on inquiry-based learning in the context of SSI to advancing HOTS need to be done. It caused to provide alternative learning information that the lecturer can use to be advancing students' HOTS. Therefore, this study aims to examine the effectiveness of inquiry-based learning with SSI as context by making the reflective ability available to improve students' higher-order thinking skills.

\section{METHOD}

This research used a between-group design with quasiexperiments pre-and post-test methods (Creswell J. W., 2012). Quasi-experiments pre-and post-test method was used because it is impossible to randomize the existing group of subjects. The experiment design of this study is shown in Table 1.

Table 1 The research design of quasi pre-and posttest

\begin{tabular}{llll}
\hline Group & Pretest & Treatment & Posttest \\
\hline EG & $\mathrm{O}_{1}$ & $\mathrm{X}$ & $\mathrm{O}_{2}$ \\
CG & $\mathrm{O}_{1}$ & $\mathrm{Y}$ & $\mathrm{O}_{2}$ \\
\hline
\end{tabular}

\section{Explanation:}

EG: Experimental Group

CG: Control Group

$\mathrm{O}_{1}$ : pretest HOTS used 20 multiple choice questions

$\mathrm{X}$ : treatment using process inquiry-based learning with socio-scientific issues as context

$\mathrm{Y}$ : treatment by utilizing verification learning

$\mathrm{O}_{2}$ : posttest HOTS used 20 multiple choice questions 
This research was conducted on first-year students who took introductory chemistry. This research was held in the even semester of 2019/2020. This research used two classes as the experimental groups (EG) (68 students) and one class as a control group (CG) (28 students). Two classes as EG were carried out to expand the research findings. Two classes as EG were given the same instruction, inquiry-based learning with SSI, while a CG was assigned verification learning. The researcher conducted the treatment in the EG, and the lecturer gave the treatment in CG. This research used chemistry topics by utilizing online media. The details of treatment are four asynchronous assignments and two synchronous assignments via room application. The treatment was carried out because it adjusted to the pandemic situation. In this situation, learning was carried out asynchronous and synchronous by online media.

The researcher developed the instruments used in this research-based competency in subject achievement and adjusted them to HOTS levels. Research instruments that were used included treatment (Worksheets \& SSI article) and measurement instruments. More concisely, the treatment scheme in this research is described in Table 2.

The measurement instruments form a HOTS test that consists of 20 multiple-choice questions. The test consists of eight questions of analyzing type (C4), seven questions of evaluating the type (C5), and five questions of creating type (C6). A higher-order thinking skill test was developed based on the indicator "action verbs" of Bloom's Taxonomy revised (Anderson \& Krathwohl, 2001). HOTS tests were developed based on acid-base topics, which multiple-choice items. The score is given a numeric value of one to correct answer and zero for incorrect. That instrument has been tested for reliability on 98 students. A validity test was conducted to determine the HOTS instrument's suitability with the ability to be measured. Two expert lecturers carried out the validity test. Based on the validity test, 10 questions out of 30 are suggested not to be used. This is because it does not match with the HOTS level. Furthermore, there are 2 questions from 20 need to revise. Validity and reliability test were conducted using SPSS 16.0 for windows. Reliability score obtained is equal to $0.812>\mathrm{r}$ table $(0.199)$. The reliability score belongs to

Table 2 Comparison of treatments in the experimental and control groups

\begin{tabular}{|c|c|c|c|c|}
\hline $\begin{array}{l}\text { Meeting } \\
\text { to- }\end{array}$ & $\begin{array}{l}\text { Discussion } \\
\text { Topics }\end{array}$ & $\begin{array}{l}\text { Time } \\
\text { Allocation }\end{array}$ & $\begin{array}{l}\text { Experimental Groups } \\
\text { (Inquiry-based learning with SSI) }\end{array}$ & $\begin{array}{l}\text { Control Group } \\
\text { (Verification Learning) }\end{array}$ \\
\hline \multirow[t]{2}{*}{1} & $\begin{array}{l}\text { Introduction } \\
\text { to Acids and } \\
\text { Bases }\end{array}$ & $\begin{array}{l}3 \times 50 \\
\text { minutes }\end{array}$ & $\begin{array}{l}\text { Students introduced to surrounding subjects } \\
\text { related to acid-base, then perform analysis of } \\
\text { other topics related to acid-base. This } \\
\text { introduction will provide an overview of the } \\
\text { relationship between the concept of acid-base } \\
\text { and daily life events so that it will attract } \\
\text { students' interest to participate actively in } \\
\text { learning. }\end{array}$ & $\begin{array}{l}\text { Students were given books on } \\
\text { acid-base materials to study } \\
\text { independently. This learning will } \\
\text { make students learn according to } \\
\text { the desired learning style but } \\
\text { focused on the lecturer's } \\
\text { resources. }\end{array}$ \\
\hline & $\begin{array}{l}\text { Acid-base } \\
\text { theory }\end{array}$ & & $\begin{array}{l}\text { Students are given the worksheet that presents } \\
\text { examples and non-examples of each acid-base } \\
\text { theory, then formulated concepts based on } \\
\text { leading questions. Such learning will train } \\
\text { students to illustrate examples that can build } \\
\text { ideas. Based on this description, students were } \\
\text { taught to analyze ideas to create conclusions } \\
\text { about the acid-base theory studied. }\end{array}$ & $\begin{array}{l}\text { Students were asked to read } \\
\text { various acid-base theories, then } \\
\text { given the assignment to } \\
\text { understand the understanding of } \\
\text { the acid-base theory proposed by } \\
\text { experts }\end{array}$ \\
\hline \multirow[t]{2}{*}{2} & $\begin{array}{l}\text { Damage to } \\
\text { coral reefs }\end{array}$ & $\begin{array}{l}3 \times 50 \\
\text { minutes }\end{array}$ & $\begin{array}{l}\text { Students were given coral reef damage, then } \\
\text { analyzed the relationship between the acid-base } \\
\text { concept and the problems presented and made } \\
\text { possible solutions. Such learning will help } \\
\text { students practice their ability to analyze } \\
\text { information in reading and evaluate existing } \\
\text { sources and data to determine the relationship } \\
\text { between coral reef damage and acid-base } \\
\text { material. }\end{array}$ & $\begin{array}{l}\text { Students understood and learned } \\
\text { acid-base calculations based on } \\
\text { material provided by the } \\
\text { lecturer. This learning will make } \\
\text { students fixated on solving the } \\
\text { problems given. }\end{array}$ \\
\hline & $\begin{array}{l}\text { Acid-base } \\
\text { calculation }\end{array}$ & & $\begin{array}{l}\text { Students in an inquiry using worksheet learned } \\
\text { acid-base calculations to then applied to a } \\
\text { problem. Such learning will train students to } \\
\text { apply the knowledge/concepts obtained to } \\
\text { similar issues or concerns that have been } \\
\text { modified. }\end{array}$ & $\begin{array}{l}\text { Students applied the formulas } \\
\text { that had been learned through } \\
\text { doing assignments given by the } \\
\text { lecturer. Learning can cause } \\
\text { students to train to use the } \\
\text { formula obtained in the same } \\
\text { case. }\end{array}$ \\
\hline
\end{tabular}


Table 2 Comparison of treatments in the experimental and control groups (continued)

\begin{tabular}{|c|c|c|c|c|}
\hline $\begin{array}{l}\text { Meeting } \\
\text { to- }\end{array}$ & $\begin{array}{l}\text { Discussion } \\
\text { Topics }\end{array}$ & $\begin{array}{l}\text { Time } \\
\text { Allocation }\end{array}$ & $\begin{array}{l}\text { Experimental Groups } \\
\text { (Inquiry-based learning with SSI) }\end{array}$ & $\begin{array}{l}\text { Control Group } \\
\text { (Verification Learning) } \\
\end{array}$ \\
\hline \multirow[t]{2}{*}{3} & Acid rain & $\begin{array}{l}3 \times 50 \\
\text { minutes }\end{array}$ & $\begin{array}{l}\text { Students associated the concept of acid-base } \\
\text { reactions with acid rain events by practicing, } \\
\text { analyzing, reading, and evaluating various } \\
\text { sources to create solutions. The acid rain event } \\
\text { will make students relate the material of acid- } \\
\text { base reaction equations and acid-base theory. }\end{array}$ & $\begin{array}{l}\text { Students were given videos } \\
\text { related to the acid-base titration } \\
\text { process and the application of } \\
\text { calculations to be studied } \\
\text { independently. Students can } \\
\text { know the process of change that } \\
\text { the sense of sight can directly } \\
\text { observe. }\end{array}$ \\
\hline & $\begin{array}{l}\text { Acid-base } \\
\text { titration }\end{array}$ & & $\begin{array}{l}\text { Students in an inquiry analyzed the processes } \\
\text { that occur in the titration implementation with } \\
\text { the worksheet's help. Then they were given a } \\
\text { similar problem to solve based on the inquiry } \\
\text { steps that had been carried out. } \\
\text { In this titration learning, students were } \\
\text { introduced to titration and trained to understand } \\
\text { the process during titration. It will make students } \\
\text { analyze the reactions that occur to evaluate what } \\
\text { substances are present during the response and } \\
\text { formulate acid/base calculations, formulate } \\
\text { buffer solutions, and salt hydrolysis. It will make } \\
\text { students apply formulas, analyze differences, and } \\
\text { evaluate problems related to events during the } \\
\text { reaction process. }\end{array}$ & $\begin{array}{l}\text { Students were given assignments } \\
\text { in the form of questions related } \\
\text { to acid-base titration as a } \\
\text { strengthening of } \\
\text { understanding. Students could } \\
\text { practice knowledge by applying } \\
\text { problem-solving steps, but } \\
\text { thinking for other problems was } \\
\text { not trained. }\end{array}$ \\
\hline 4 & Verification & $\begin{array}{l}3 \times 50 \\
\text { minutes }\end{array}$ & $\begin{array}{l}\text { Students conducted face-to-face discussions and } \\
\text { lectures via zoom to discuss concepts that are not } \\
\text { yet understood and addressed the relationship } \\
\text { between the problem and the acid-base idea. }\end{array}$ & $\begin{array}{l}\text { Students were given questions to } \\
\text { work on as an exercise before } \\
\text { the measurement process was } \\
\text { carried out }\end{array}$ \\
\hline
\end{tabular}

the high category based on Arikunto (2014). The difficulty index of 20 question: four questions with difficult $(n=0.259$ - 0.283) category, and 16 questions with moderate $(n=0.322-0.566)$ category. Based on these results, the instrument of a HOTS test is declared decent to use. Examples of the HOTS test are presented in Table 3.

Data analysis that was carried out in this study includes a preconditioning test and a different test. A precondition test was used to determine the average HOTS before the treatment is carried out. The difference test was carried out to determine how much affect the treatment for advancing

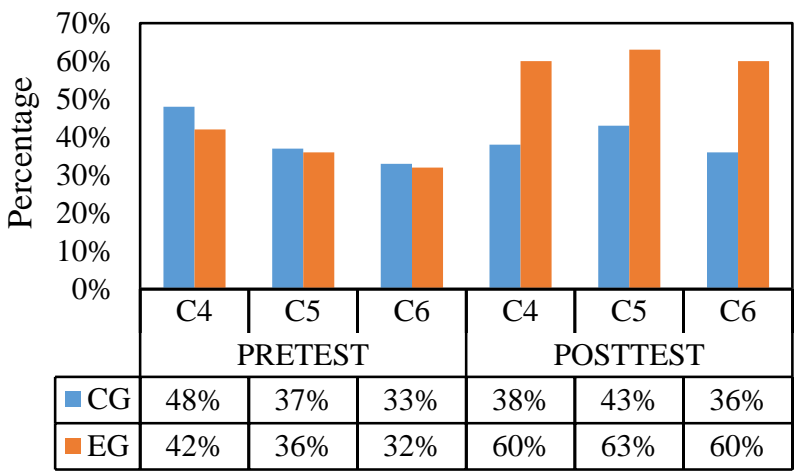

Figure 1 The percentage achieving each level of HOTS students' HOTS. The details of data analysis in this research are described as follows. Precondition test. It includes normality and homogeneity tests followed by oneway ANOVA. The normality test used the Shapiro-Wilk method, while the homogeneity test used Levene statistic. Each test was utilizing SPSS 16.0 for windows as assistance. The difference test used ANOVA followed by an effect size test. Both tests were utilizing SPSS 16.0 for windows as assistance by using the post-test score.

\section{RESULT AND DISCUSSION}

The pretest data showed that the experimental and control groups' HOTS level was normal $(\mathrm{p}=0.100$ for EG; $p=0.147$ for $C G)$ and homogeny $(p=0.976)$. The one-way ANOVA test results showed no significant difference in students' pre-higher order thinking skills achievement scores for the CG and students in the EG ( $p=0.405)$. The resulting ANOVA is described in Table 4. After treatment, post-test data showed that there was advancing on the average score of the HOTS test. The resulting score of HOTS tests before and after treatment is described in Table 5 and Figure 1.

Furthermore, the normality and homogeneity tests were carried out based on post-test to determine data distribution. The normality and homogeneity test showed 
Table 5 Pre-and posttest data of Higher-Order Thinking Skills

\begin{tabular}{lll}
\hline Class & Average Score & \\
\cline { 2 - 3 } & Pretest & Posttest \\
\hline EG & 40 & 68 \\
CG & 38 & 40 \\
\hline
\end{tabular}

that data of $E G(p=0.200)$ and $C G(p=0.535)$ was normal and homogeny $(\mathrm{p}=0.609)$. Caused by the results, ANOVA was conducted to compare the students' HOTS achievement in the CG and EG by utilizing SPSS 16.0 for windows as assistance. Table 6 showed that score of significance $<0.05$. It means there was a significant difference in students' HOTS level for the CG and EG. Details of the differences in students' HOTS level EG and CG are shown in Figure 1.

Figure 1 showed that in each level of higher-order thinking skills in the students who treatment by inquirybased learning with SSI as context were higher than the CG

Table 4 The result of one-way ANOVA pre-higher order thinking skills

\begin{tabular}{llllll}
\hline Category & Sum of Squares & df & Mean Square & F & Sig. \\
\hline Between Groups & 127.103 & 1 & 127.103 & .701 & .405 \\
Within Groups & 17047.637 & 94 & 181.358 & & \\
Total & 17174.740 & 95 & & & \\
\hline
\end{tabular}

Table 3 Examples questions of HOTS

\begin{tabular}{|c|c|c|}
\hline $\begin{array}{l}\text { Questions } \\
\text { Level }\end{array}$ & Questions Indicator & Questions \\
\hline $\begin{array}{l}\text { C6 } \\
\text { Creating }\end{array}$ & $\begin{array}{l}\text { Presented with } \\
\text { statements and } \\
\text { examples of Lewis acid- } \\
\text { base reaction, students } \\
\text { can determine the right } \\
\text { hypothesis about the } \\
\text { fundamental } \\
\text { development of Lewis } \\
\text { acid-base theory. }\end{array}$ & $\begin{array}{l}\text { The limitation of the Bronsted-Lowry acid-base concept is explaining reactions } \\
\text { involving compounds without } \mathrm{H}^{+} \text {, such as the reaction between copper (II) and } \\
\text { ammonia ions that produce complex tetraamincopper (II) ions. } \\
\text { This limitation then became the basis for the development of Lewis's acid-base } \\
\text { theory. } \\
\text { Based on this statement, determine the correct hypothesis based on Lewis acid- } \\
\text { theory development! } \\
\text { a. Lewis's acid-base theory is based on proton donors and acceptors, where } \\
\text { ammonia acts as a proton donor, while the copper (II) ion acts as a proton } \\
\text { acceptor. }\end{array}$ \\
\hline
\end{tabular}

b. Lewis's acid-base theory is based on electron-pair donors and acceptors to form covalent bonds between the bonding species, in which ammonia acts as a base and the copper ion acts as an acid.

c. Lewis's acid-base theory is based on the formation of coordinate covalent bonds. The species donating an electron pair acts as a base, and the electronpair acceptor acts as an acid.

d. Lewis acid-base theory is based on the donor and acceptor of the central atom's lone pair. The ammonia species as an electron-pair donor acts as a base, and the copper ion as an acceptor is acidic.

e. Lewis acid-base theory is based on the formation of stable compounds, in which species that have unstable lone pairs will bind to species without more stable lone pairs.

\begin{tabular}{ll}
\hline C5 & Given a sub- \\
Evaluating & microscopic \\
& representation of the \\
& species present in a \\
& solution, students can \\
predict pictures that are & unlikely to occur in a \\
& weak acid solution. \\
& (make guesses based on \\
particular criteria)
\end{tabular}

Submicroscopic figures can represent species present in acidic and alkaline solutions. In the Bronsted Lowry acid-base context, the most unlikely submicroscopic representation of a diprotic acid solution, $\mathrm{H}_{2} \mathrm{~A}$, is in an aqueous solution? (Water molecule not drawn)

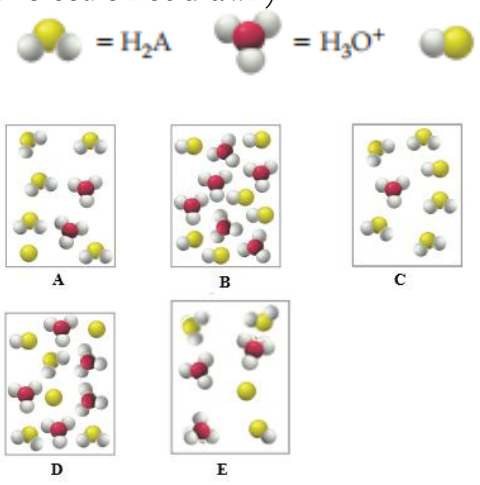


Table 3 Examples questions of HOTS (Continued)

\begin{tabular}{|c|c|}
\hline $\begin{array}{l}\text { Questions } \\
\text { Level }\end{array}$ & Questions Indicator \\
\hline $\begin{array}{l}\text { C4 } \\
\text { Analyzing }\end{array}$ & $\begin{array}{l}\text { Students can analyze } \\
\text { errors in the practical } \\
\text { steps to make a } \\
\text { particular pH solution, } \\
\text { based on the facts and } \\
\text { reasonable measures. } \\
\text { (analyze the elements } \\
\text { by separating the } \\
\text { problem into its } \\
\text { components) }\end{array}$ \\
\hline
\end{tabular}

Questions

Nahda wants to make a sodium hydroxide solution with a $\mathrm{pH}$ of 10.3 using solid

$\mathrm{NaOH}$. The steps used by Nahda are as follows!

1. Weighing solid $\mathrm{NaOH}$ using glass as much as $8.00 \mathrm{~g}$.

2. Dissolve solid $\mathrm{NaOH}$ in a beaker with distilled water. The volume of distilled water is $\pm 10 \mathrm{ml}$.

3. After all solid $\mathrm{NaOH}$ dissolves, please put it in a $1000 \mathrm{ml}$ measuring flask. Then add distilled water to mark the limit. Shaken until homogeneous

4. $10 \mathrm{~mL}$ of the solution were taken using a volume pipette. Then put in another $1000 \mathrm{~mL}$ measuring flask.

5. Diluted by adding distilled water to mark boundaries. Shaken until homogeneous.

6. The solution formed is then taken $10 \mathrm{~mL}$ to measure the $\mathrm{pH}$ using a $\mathrm{pH}$ meter. Based on the experiments that Nahda has done, it turns out that the $\mathrm{pH}$ of the solution formed is \pm 11.3 . Determine which step of the Nahda experiment was incorrect!

a. Step 2. In this step, $\mathrm{Nahda}$ should immediately put the solid $\mathrm{NaOH}$ into the measuring flask so that no $\mathrm{NaOH}$ is left in the beaker geals.

b. Step 1. In this step, Nahda should not have weighed $\mathrm{NaOH}$ immediately but did the calculations first so that the amount of solid $\mathrm{NaOH}$ was considered right.

c. Steps 3 and 4 . In these steps, Nahda should use a $100 \mathrm{~mL}$ measuring flask to dilute the solution formed.

d. Step 5. In this step, shaking should not be needed because it allows the $\mathrm{NaOH}$ solution to spill so that the water content is reduced and the solution becomes more concentrated than before.

e. Step 4. In this step, you should use a measuring cup to take the solution so that the accuracy level is higher than before.

Table 6 The result of one-way ANOVA post-higher order thinking skills

\begin{tabular}{llllll}
\hline Category & Sum of Squares & Df & Mean Square & F & Sig. \\
\hline Between Groups & 15764.741 & 1 & 15764.741 & 60.636 & .000 \\
Within Groups & 24439.092 & 94 & 259.990 & & \\
Total & 40203.833 & 95 & & & \\
\hline
\end{tabular}

Table 7 The results of effect size

\begin{tabular}{|c|c|c|c|c|c|c|c|c|c|c|}
\hline \multirow[t]{2}{*}{ Aspect } & \multirow{2}{*}{$\begin{array}{l}\text { Effect } \\
\text { Size }\end{array}$} & \multirow{2}{*}{$\begin{array}{l}\text { Mean } \\
\text { Difference }\end{array}$} & \multicolumn{2}{|c|}{ Mean } & \multirow{2}{*}{$\begin{array}{l}\text { Std. Error } \\
\text { Difference }\end{array}$} & \multicolumn{2}{|c|}{ Std. Deviation } & \multicolumn{3}{|c|}{ Partial Eta Squared } \\
\hline & & & CG & EG & & CG & EG & $\begin{array}{l}\text { Corrected } \\
\text { Model }\end{array}$ & Intercept & Group \\
\hline HOTS & 1,90976 & 28.193 & 39.57 & 67.76 & 2.984 & 10.905 & 17.800 & 0,392 & 0,903 & 0,392 \\
\hline
\end{tabular}

who treatment by verification learning. It means that inquiry-based learning with SSI as the context affected students' HOTS. That meaningfulness is also followed by the effect size score, which shows a score of 1.909. It led to a high contribution to the learning method based on Becker (2000) to advancing HOTS among classes that treat inquiry-based learning with SSI as context and verification learning. The result test effect size showed in Table 7.

Higher-order thinking skills are related to meaningful learning (Aksela, 2005), increasing reading comprehension (Indriyana \& Kuswandono, 2019), and scientific literacy (Rahayu, 2016; Subiantoro, 2017). The results showed that treatment acid-base inquiry with SSI as the context has HOTS that better verifies learning with a high contribution. This result is possible because students in the
EG are accustomed to being actively involved in understanding concepts by analyzing problems and evaluating various sources and evidence to synthesize them into understanding. Teaching strategy that involves students to active would play an essential role in long-term memory. It will enhance meaningful learning that leads students to apply it in other conditions (Bahrick \& Hall, 1991; Slavin, 2019).

Although the data pretest showed that both groups have equal level HOTS, students already understand the concept. However, students in the CG have not solved problems that require higher thinking skills than just memorizing, understanding, and applying. SSI in the EG will train students to analyze the issues and evaluate evidence and sources to solve them. The implementation 
of SSI can encourage students to actively engage in dialogue, discussion, and debate to provide a challenge to evaluate knowledge and provide an opportunity to rebuild mastery of concepts related to the concepts they have (Cahyarini, Rahayu, \& Yahmin, 2016).

The issues in treatment related to acid rain, damage to coral reefs, and the use of Steam Electric Power Generating (SEPG) are the contexts of SSI conflicting. For example, using SEPG as a power plant will produce substances that can cause acid rain or damage coral reefs (Middlecamp, et al., 2012). On the other side, SEPG in Indonesia is the primary electricity source (Yatim, 2007). Such problems are complex and related to morals and ethics that can lead to conflict. Because of conflict in the context of SSI, it can lead students to analyze, evaluate, and create solutions (Kitchener \& King, 1981; Zeidler, Sadler, Applebaum, \& Callahan, 2009). The existence of problems with the SSI context will provide many opportunities for students to exchange ideas with one another. Because SSI problems involve science and social problems, arguments need to be built from various perspectives (Sadler, 2004). Such a process will make students think carefully by paying attention to various sources before making a final decision (Pratiwi, Rahayu, \& Fauziatul, 2016). In the process of consideration, students will train three essential aspects, namely (1) students need to analyze so that they can understand and describe SSI problems; (2) students formulate several possible solutions to problems; and (3) students need to evaluate decisions that have been made before the decisions are submitted (Ratcliffe \& Grace, 2003). Based on that study, it can be concluded that the context of SSI in the treatment affects students' higherorder thinking skills (analyzing, evaluating, and creating).

Students in the treatment class have also been accustomed to getting a concept with the inquiry process presented in each topic. The inquiry process will actively involve students through activities, namely understanding problems, identifying problems, then making conclusions to make concepts or solutions (Aksela, 2005; Hendryarto \& Amaria, 2013; Kaltakci \& Oktay, 2011). These activities will encourage students to practice HOTS. The lecturer in inquiry learning plays an essential role as a motivator, facilitator, and director in learning. The lecturer as a motivator has a function to encourage students to provide opinions on the SSI. As a facilitator, the lecturer functions to provide context SSI that can make students think actively and have a function to show solutions if there are obstacles in the learning process. The lecturer as a director has a function to lead students in the thinking process to achieve the expected goals.

Previous research has shown that inquiry-based learning needs to be done to improve higher-order thinking skills (Malik, Ertikanto, \& Suyatna, 2015). Inquiry showed success in improving higher-order thinking skills (Aksela, 2005; Kaltakci \& Oktay, 2011; Madhuri, Kantamreddi, \&
Goteti, 2012). Inquiry-based learning with SSI can enhance critical thinking skills (Mahanani, Rahayu, \& Fajaroh, 2020). Based on the study and the results of these studies, it can be concluded that inquiry-based learning applied to treatment also affects students' higher-order thinking skills. Inquiry learning provides benefits for students, including (a) students learn to be responsible for gaining knowledge and assignment that given; (b) students are free to use various media, sources, and technic of constructing knowledge; and (c) students learn to develop his ability and solve the problem on his way.

In addition to the context and methods used in the treatment class, the learning process that involves discussion for verifying students' understanding is also a factor in training students' higher-order thinking skills to understand acid-base. Confirming students' understanding used in the treatment class was not intended to teach or provide training. The comprehension verification process is used to determine whether students understand what they have learned (Slavin, 2019). The treatment class's discussion process was carried out by being briefed with questions to get the correct concept. Fisher \& Frey (2007) state that educators can use questions as an examination of understanding. Questions asked to encourage students to think about ideas will help them understand concepts (Sadker \& Sadker, 2013; Slavin, 2019).

Meanwhile, in the classroom with verification learning, students only build their understanding, but there is less guidance in obtaining the correct concept. An independent learning process in the verification class also allows students to practice HOTS. The separate learning process will cause students to adjust to learning styles, but it will also have different impacts (Slavin, 2019). However, experiments have also shown that learning with verification is no better than inquiry-based learning, either with a guided inquiry or open inquiry (Aksela, 2005; Hendryarto \& Amaria, 2013; Mahanani, Rahayu, \& Fajaroh, 2020; Malik, Ertikanto, \& Suyatna, 2015); as well as other contextual learning, such as problem-based learning (Magsino, 2014; Sismawarni, Usman, Hamid, \& Kusumaningtyas, 2020). Besides, in verification learning, students are not trained intensively to lead to wrong understanding or students only to memorize and apply what the educators give. Students in the verification class are also not prepared to relate various problems around them, causing them to focus on concepts without applying them to situations around them that tend to be the same.

\section{CONCLUSION}

This study concluded that process inquiry-based learning with SSI as context could be advancing students' higher-order thinking skills. It showed an enhancement of EG's average post-test score and the result ANOVA that followed the effect size. Higher-order thinking skills are successful because in inquiry-based learning with SSI environment, real-life problem scenarios are used. It also 
encourages students to engage themselves in the learning process. Inquiry-based learning with SSI as context gives a high contribution to advance students' higher-order thinking skills.

\section{REFERENCES}

Aksela, M. (2005). Supporting Meaningful Chemistry Learning and HigherOrder Thinking through Computer-Assisted Inquiry: A Design Research Approach. Helsinki: University of Halsinky.

Anderson, L. W., \& Krathwohl, D. R. (2001). A Taxonomy for Learning, Teaching, and Assessing. Boston: MA: Allyn and Bacon.

Arikunto, S. (2014). Prosedur Penelitian Suatu Pendekatan Praktik (Research Procedure A Practical Approach). Jakarta: Rineka Cipta.

Bahrick, H. P., \& Hall, L. K. (1991). Lifetime Maintenance of High School Mathematics Content. Journal of Experimental Psychology: General, 20-33.

Becker, L. A. (2000). Effect Size ( ES ). Universitat de València' https://www.uv.es/ friasnav/EffectSizeBecker.pdf

Brookhart, S. M. (2010). How to Asses Higher Order Thinking Skills in Your Classroom. USA: ACSD.

Cahyarini, A., Rahayu, S., \& Yahmin. (2016). The Effect of 5E Learning Cycle Instructional Model Using Socioscientific Issues (SSI) Learning Context on Students' Critical Thinking. Jurnal Pendidikan IP A Indonesia, 222-229.

Cardellini, L. (2012). Chemistry: Why the Subject is Difficult? / Química: ¿Por Qué la Disciplina es Difícil? Educación Química, 305-310.

Creswell, J. W. (2012). Educational Research: Planning, Conducting, and Evaluating Quantitative and Qualitative Research. Boston: Pearson Education, Inc.

Eastwood, J. L., Sadler, T. D., Zeidler, D. L., Lewis, A., Amiri, L., \& Applebaum, S. (2012). International Journal of Science Contextualizing Nature of Science Instruction in Socioscientific Issues. International Journal of Science Education Vol. 34, 2289-2315.

Fisher, D., \& Frey, N. (2007). Checking for Understanding: Formative Assessment Technique for Your Classroom. Alexandria: ACSD.

Graber, W., Neumann, A., Erdmann, T., \& Schlieker, V. (2006). ParIS: A Partnership Between Industry and School. In P. Nentwig, \& D. Waddington, Making It Relevant: Context Based Learning of Science (pp. 249-272). New York: Waxman Munster.

Hendryarto, J., \& Amaria. (2013). Penerapan Model Pembelajaran Inkuiri untuk Melatih Kemampuan Berpikir Tingkat Tinggi Siswa pada Materi Pokok Laju Reaksi [Application of Inquiry Learning Model to Train Students' High-Order Thinking Skills in Reaction Rate Topics]. Journal of Chemical Education, 151-158.

Imaduddin, M., \& Khafidin, Z. (2018). Ayo Belajar IPA dari Ulama : Pembelajaran Berbasis Socio-scientific Issues di Abad ke-21 (Let's Learn Science from Ulama: Learning Based on Socio-scientific Issues in the 21st Century). Thabiea: Journal of Nature Science Teaching, 102-120.

Indriyana, B. S., \& Kuswandono, P. (2019). Developing Students' Higher Order Thinking Skills (HOTS) in Reading: English Teachers' Strategies in Selected Junior High Schools. JET Journal of English Teaching), 2014-216.

Kaltakci, D., \& Oktay, O. (2011). A Guided-Inquiry Laboratory Experiment to Reveal Students' Comprehension of Friction Concept: A Qualitative Study. Balkan Physics Letters. Ankara: Bogazici University Press., 180-190.

Kitchener, K. S., \& King, P. M. (1981). Reflective Judgment: Concepts of Justification and Their Relationship to Age and Education. Journal of Applied Developmental Psychology, 89-116.

Kristiana, T., Afandi, \& Wahyuni, E. S. (2019). Potensi Socioscientific Issues dalam Memberdayakan Kemampuan Berpikir Kritis Siswa (Potential of Socioscientific Issues in Empowering Students' Critical Thinking Skills). Prosiding Seminar Nasional FKIP 2019 "Optimalisasi Kualitas Pembelajaran Abad 21 di Era Revolusi Industri 4.0 dalam Menghasilkan Pendidikan yang Profesional" (pp. 260-266). Pontianak: Universitas Tanjungpura.

Madhuri, G. V., Kantamreddi, V. S., \& Goteti, L. N. (2012). Promoting Higher Order Thinking Skills Using Inquiry-Based Learning. European Journal of Engineering Education, 117-123.

Magsino, R. M. (2014). Enhancing Higher Order Thinking Skills in a Marine Biology Class through Problem-Based Learning. Asia Pasific Journal Multidisciplinary Research, 1-6.

Mahanani, I., Rahayu, S., \& Fajaroh, F. (2020). The Effect of Inquiry Based Learning with Socioscientific Issues Context on Critical Thinking Skills and Scientific Explanation. Jurnal Kependidikan: Penelitian Inovasi Pembelajaran, 53-68.

Malik, A., Ertikanto, C., \& Suyatna, A. (2015). Deskripsi Kebutuhan HOTS Assessment pada Pembelajaran Fisika dengan Metode Inkuiri Terbimbing (Description of HOTS Assessment Needs in Physics Learning with Guided Inquiry Method). Prosiding Seminar Nasional Fisika SNF 2015, (pp. 1-4).

Middlecamp, C. H., Keller, S. W., Anderson, K. L., Bentley, A. K., Cann, M. C., \& Ellis, J. P. (2012). Chemistry in Context: Applying Chemistry to Society. New York: McGraw-Hill.

Nurohman, S., Wibowo, W. S., \& Widhi H, P. (2013). Model Integrated Science Berbasis Socio Scientific Issues untuk Mengembangkan Thinking Skills dalam Mewujudkan 21st Century Skills (Integrated Science Model Based on Socio Scientific Issues to Develop Thinking Skills in Realizing 21st Century Skills). Jurnal Pendidikan Matematika dan Sains Tabun I, No. 2, 158-164.

Paraskeva-Hadjichambi, D., Hadjichambis, A. C., \& Korfiatis, K. (2015). How Students' Values are Intertwined with Decisions in a Socioscientific Issue. International Journal of Environmental \& Science Education, 493-513.

Pratiwi, Y. N., Rahayu, S., \& Fauziatul, F. (2016). Socioscientific Issues (SSI) in Reaction Rates Topic and Its Effect on The Critical Thinking Skills of High School Students. Jurnal Pendidikan IPA Indonesia, 164-170.

Rahayu, S. (2016). Mengembangkan Keterampilan Tingkat Tinggi Siswa Melalui Pembelajaran Kimia Berkonteks Socioscientific Issues (SSI) dan Nature of Science (NOS) [Developing Students' HighOrder Thinking Skills Through Chemistry Learning in the Context of SSI and NOS]. Seminar Nasional Kimia dan Pembelajarannya, (pp. 11-19).

Ratcliffe, M., \& Grace, M. (2003). Science Education for Citizenship: Teaching Socio-Scientific Issues. United Kingdom: McGraw-Hill Education (UK).

Sadker, M., \& Sadker, D. (2013). Questioning Skills. In J. M. Cooper, Classroom Teaching Skills (pp. 121-168). USA: Wadsworth.

Sadler, T. D. (2004). Informal Reasoning Regarding Socio-scientific Issues : A Critical Review of Research. Journal of Research in Science Teaching, 513-536.

Sadler, T. D. (2009). Situated Learning in Science Education: Socioscientific Issues as Contexts for Practice. Studies in Science Education, $1-42$.

Sadler, T. D., \& Murakami, C. D. (2014). Socio - scientific Issues Based Teaching and Learning: Hydrofracturing as An Illustrative Context of a Framework for Implementation and Research. Revista Brasileira de Pesquisa em Educação em Ciências, 331-342.

Sadler, T. D., \& Zeidler, D. L. (2004). The Morality of Socio-scientific Issues: Construal and Resolution of Genetic Engineer Dilemmas. Science Education, 88(1), 4-27.

Shidiq, A. S., Masykuri, M., \& Susanti, E. (2015). Analisis Higher Order Thinking Skills (HOTS) Menggunakan Instrumen Two-Tier Multiple Choice pada Materi Kelarutan dan Hasil Kali Kelarutan untuk Siswa Kelas XI SMAN 1 Surakarta (Analysis of Higher Order Thinking Skills (HOTS) Using Two-Tier Multiple Choice Instruments on Solubility Topics for $2^{\text {nd }}$ Grade Senior High School 1 Surakarta Students). Seminar Nasional Pendidikan Sains "Pengembangan Model dan Perangkat Pembelajaran", (pp. 159-166). Surakarta. 
Sismawarni, W. U., Usman, Hamid, N., \& Kusumaningtyas, P. (2020). Pengaruh Penggunaan Isu Sosiosaintifik dalam Model Pembelajaran Berbasis Masalah Terhadap Keterampilan Berpikir Tingkat Tinggi Siswa (The Effect of Using Socioscientific Issues in Problem Based Learning Models on Students' High Order Thinking Skills). Jambura Journal of Educational Chemistry, 10-17.

Slavin, R. E. (2019). Psikologi Pendidikan Teori dan Praktike (Educational Psychology Theory and Practice). Jakarta: PT Indeks.

Subiantoro, A. W. (2017). Pembelajaran Biologi Berbasis Socio-scientific Issues ( SSI ) untuk Mengasah Keterampilan Berpikir Tingkat Tinggi (Biology Learning Based on Socio-scientific Issues (SSI) to Train Higher-Order Thinking Skills). Seminar Nasional Pendidikan Biologi.

Tsaparlis, G. (2020). Higher and Lower-Order Thinking Skills: The Case of Chemistry Revisited. Journal of Baltic Science Education, 467-483.

Yatim, E. M. (2007). Dampak dan Pengendalian Hujan Asam (Impact and Control of Acid Rain). Jurnal Kesehatan Masyarakat, 146-151.

Zeidler, D. L., \& Nichols, B. (2009). Socio-scientific Issues : Theory and Practice. Journal of Elementary Science Education, 49-58.

Zeidler, D. L., Sadler, T. D., Applebaum, S., \& Callahan, B. E. (2009). Advancing Reflective Judgment through Socio-scientific Issues. Journal of Research in Science Teaching, 74-101 